\title{
Generating Organic Liquid Products from Catalytic Cracking of Used Cooking Oil over Mechanically Mixed Catalysts
}

\author{
Khajornsak Onlamnao, Sanphawat Phromphithak, Nakorn Tippayawong*
}

Department of Mechanical Engineering, Faculty of Engineering, Chiang Mai University, Chiang Mai 50200 Thailand

\begin{abstract}
Used cooking oil is unsuitable to use again in the food process, but it may be harnessed as raw material in biofuel production. In this work, used palm oil was reacted via cracking over mechanically mixed catalysts between ZSM-5 and Y-Re-16 to generate organic liquid products (OLP). The catalysts used were known for high acidity and low cost for decomposition, degradation, and deoxygenation of triglycerides. The cracking experiments were conducted in a flow reactor. The experimental variables included reaction temperature between $300-500{ }^{\circ} \mathrm{C}$, catalyst loading between $5-20 \% \mathrm{w} / \mathrm{w}$, and ratio of mixed catalyst between ZSM-5 and Y-Re- 16 from 0-100 \% w/w. They were set via response surface methodology and central composite design of experiments. Both catalysts showed good cracking reaction. The optimum condition for generating the OLP of about $85 \% \mathrm{w} / \mathrm{w}$ was found at $300{ }^{\circ} \mathrm{C}, 5 \%$ catalyst loading, $97 \%$ ratio of mixed catalyst. The OLPs with different short-chain hydrocarbons between $\mathrm{C}_{7}-\mathrm{C}_{21}$ were identified. The main components were $71.43 \%$ of diesel, $12.11 \%$ of gasoline, and $8.95 \%$ of kerosene-like components. C2020. CBIORE-IJRED. All rights reserved
\end{abstract}

Keywords: Biomass, Biofuels, Organic liquid fuels, Renewable energy, Vegetable oils

Article History: Received: $3^{\text {rd }}$ January 2020; Revised: $3^{\text {rd }}$ March 2020; Accepted: $5^{\text {th }}$ March 2020; Available online: $2^{\text {nd }}$ May 2020

How to Cite This Article: Onlamnao, K., Phromphithak, S., and Tippayawong, N. (2020) Generating organic liquid products from catalytic cracking of used cooking oils over mechanically mixed catalysts. International Journal of Renewable Energy Development, 9(2), 159-166 https://doi.org/10.14710/ijred.9.2.157-166

\section{Introduction}

Major energy sources utilized in the world are from fossil fuels (coal, petroleum, natural gas, bitumen, tar sands, and heavy oils). They are hydrocarbon- containing materials from biological origins millions of years ago. Burning of fossil fuels is the main reason to produce greenhouse effect (Karmaker et al., 2020) because it releases gas pollutants such as carbon dioxide $\left(\mathrm{CO}_{2}\right)$, carbon monoxide ( $\left.\mathrm{CO}\right)$, sulfur-containing, and nitrogen oxide ( $\mathrm{NO}$ ) (Crabbe et al., 2001). Finite nature of fossil fuels provokes the determination to search for alternative fuels. Hence, a good alternative fuel should be in comprehensive with energy conservation, sustainable development, and more importantly environmental preservation.

Biofuel is an interesting alternative energy. It can be produced from wastes such as animal fats and vegetable oils (Syah Putra et al. 2014; Suwannapa and Tippayawong, 2017). The waste cooking oil from food industry has been generated in a large quantity per year. These vegetable oils cannot be used directly in engine because they had poor properties; high viscosity, and lower volatility (Rathore $e t$ al., 2016). The vegetable oils may need transformation to biofuel, which can be upgraded in many ways. Transesterification is a common process to produce biodiesel (Al Sharifi and Znad, 2019). It changes fatty acid and triglycerides into ethyl/methyl esters by esterification and transesterification with short- chain alcohols (Pascoal et al., 2020). Although it is widely used in biodiesel production, it has to use perilous catalysts and solvents (Nguyen et al., 2019).

Hydrocracking process is a general refining technique to remove hazardous compounds such as nitrogen, sulfur and oxygen (Li et al., 2019), but it requires high hydrogen pressure and high catalyst quality. Pyrolysis is a method to crack heavy oil molecules at high pressure, high temperature, and low oxygen without catalyst (Khuenkaeo and Tippayawong, 2018; 2020) . The liquid fuel from pyrolysis of hydrocarbon is low in quality and volume. Moreover, general products of this process have a lot of oxygen and water content (Prasertpong and Tippayawong, 2019) and inconstancy (Maher and Bressler, 2007).

Catalytic cracking is a process that can be applied to convert viscous raw materials into lighter products ( Jaroenkhasemmeesuk et al., 2018). The process of cracking vegetable oils can be explained in two stages known as primary and secondary cracking. The primary cracking is breaking triglycerides by the formation of acid on catalysts through the decomposition of triglyceride molecules which occurs on $\mathrm{C}-\mathrm{O}$ bonds within the glyceride part. The secondary cracking is characterized by degradation of the primary cracking products leading to

\footnotetext{
* Corresponding author: n.tippayawong@yahoo.com
} 
hydrocarbons with properties similar to petroleum products.

Various catalysts have been studied to produce hydrocarbons from oils and fats. Zeolite has been reported as a main catalyst for biofuel production (Benavides et al., 2017; Zhao et al., 2015; Khammasan et al., 2018). Emori et al. (2017) studied liquid fuel production from soybean oil with catalytic cracking using ZSM-5 zeolite under $\mathrm{H}_{2}$ flow. The result showed that ZSM-5 zeolite was a good catalyst. The gas flow was found to affect amount of liquid products. The advantage of ZSM- 5 is its high flexibility since the ratio of the additive to the catalysts can range widely from 0.8 to $12 \%$ w/w ( Schipper et al., 1988). Y-zeolite catalyst was accepted to be effective at deoxygenating biomass derived molecules (Hosseinpour et al., 2009; Corma et al., 2007). Zheng et al. (2017) synthesized ultra-stable Y zeolites for jatropha seed oil catalytic cracking process. The $\mathrm{Y}$ zeolite affected octane number and quantity of obtained products.

Khammasan and Tippayawong (2018) reported catalytic cracking of beef tallow using ZSM-5 to generate a light liquid fuel. The highest liquid conversion of $73 \% \mathrm{w} / \mathrm{w}$ was obtained at $443{ }^{\circ} \mathrm{C}, 60 \mathrm{~min}$ and catalyst loading of 6.3 $\% \mathrm{w} / \mathrm{w}$. Jaroenkhasemmeesuk (2017) compared the yield of light oil product from catalytic cracking of bio-oil using the single catalyst as ZSM-5 and mechanically mixed catalysts (ZSM-5 and Y-Re-16). The result showed that using ZSM5 and Y-Re-16 could produce more light oil yield than using a single ZSM-5, increasing to $75.63 \%$ from $66.82 \%$ of light oil yields. The ZSM- 5 and Y-zeolite catalysts proved to be good at cracking oils, which can decompose and degrade heavy molecular compounds. To the authors' knowledge, research studies on producing biofuel via cracking of used cooking oils (UCO) with mixed catalysts remain scare.

In this work, catalytic cracking of used palm oil over mechanically mixed catalysts between ZSM-5 and Y-Re-16 was carried out. Influences of temperature, catalyst volume, and ratio of mixing catalysts were investigated via statistical design of experiments. The optimum operating conditions were evaluated via response surface methodology (RSM) combine with central composite design (CCD). The liquid products were also characterized for important physical and chemical properties.

\section{Materials and Methods}

\subsection{Raw materials}

UCO was collected from a canteen of Chiang Mai University. Chemicals were supplied from ACS Material including hexane $\left(\mathrm{C}_{6} \mathrm{H}_{14}\right)$, acetone $\left(\mathrm{C}_{3} \mathrm{H}_{6} \mathrm{O}\right)$, dichloromethane $\left(\mathrm{CH}_{2} \mathrm{Cl}_{2}\right)$, and catalysts. The Y-Re-16 and ZSM-5 catalysts characteristics are shown in Table 1.

\subsection{Experiment setup and procedure}

The experimental setup consists of three main parts; evaporation, reactor, and condensation, shown in Fig. 1. In the evaporation part, $380 \mathrm{~W}$ heating mantle was used for heating substrate in $1000 \mathrm{~mL}$ flask. The reactor made from stainless steel $(70 \mathrm{~mm}$ in diameter, length of $150 \mathrm{~mm}$, thickness of $5 \mathrm{~mm}$ ), was wrapped around by two-band heater ( $1 \mathrm{~kW}$ for each). The catalysts were placed in the middle socket of the reactor. The condensation part was composed of a dry-ice condenser trap and coil condenser that held temperature at $-32{ }^{\circ} \mathrm{C}$ and $40{ }^{\circ} \mathrm{C}$, respectively.

Table 1

Characteristics of ZSM-5 and Y-Re-16

\begin{tabular}{lll}
\hline Appearance & ZSM-5, solid & Y-Re-16, solid \\
\hline Shape & Cylinder & Pellet \\
Dimension & $2 \mathrm{~mm}$ diameter, & $2-3 \mathrm{~mm} \mathrm{diameter,}$ \\
& $2-10 \mathrm{~mm}$ long & $10-20 \mathrm{~mm} \mathrm{long}$ \\
$\mathrm{SiO}_{2} / \mathrm{Al}_{2} \mathrm{O}_{3}$ ratio & 38 & 5 \\
Pore volume & $\geq 0.25 \mathrm{~cm}^{3} / \mathrm{g}$ & $0.3-0.5 \mathrm{~cm}^{3} / \mathrm{g}$ \\
BET surface area & $\geq 250 \mathrm{~m}^{2} / \mathrm{g}$ & $\geq 620 \mathrm{~m}^{2} / \mathrm{g}$ \\
\hline
\end{tabular}

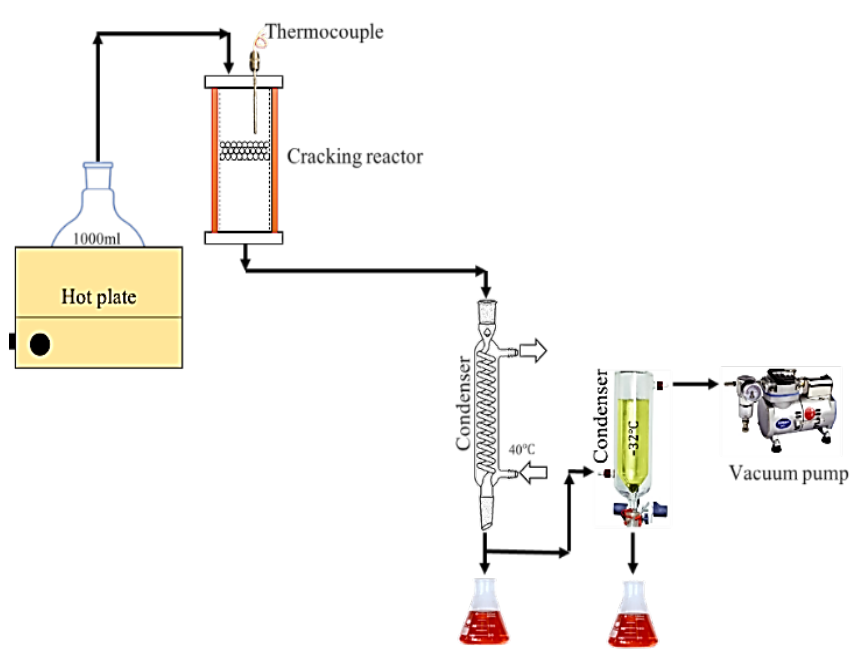

Fig. 1 Schematic of the experimental setup

The ZSM-5 and Y-Re-16 catalysts were prepared by calcination at $350{ }^{\circ} \mathrm{C}$ for $4 \mathrm{~h}$ in an oven for removing moisture, similar to that reported in Jaroenkhasemmeesuk et al., (2017). The active catalysts were then placed in the middle socket of the reactor. For catalyst mixture preparation, ZSM-5 and Y-Re-16 were mixed via mechanical stirring for $30 \mathrm{~min}$. The UCO was cleaned by washing with water, then filtered by $125 \mathrm{~mm}$ diameter filter paper. After that, the UCO was heated at $105{ }^{\circ} \mathrm{C}$ for $30 \mathrm{~min}$ to remove moisture. All experiments used $100 \mathrm{~g}$ of UCO, which was added to the flask. The UCO was heated and allowed to vaporize at $250{ }^{\circ} \mathrm{C}$. Its weight loss rate was monitored and found to be about $1 \mathrm{~g} / \mathrm{min}$ of evaporation rate. The UCO vapor flew through stainless steel pipe ( $5 \mathrm{~mm}$ of diameter) into the reactor, where it was heated up to the preset temperature. The UCO vapor reacted with the catalysts to generate gas, with a gas hourly space velocity of about $0.166 \mathrm{~h}^{-1}$. The reacted oil vapor was cooled down through the condenser systems and collected in the form of organic liquid product (OLP). The yield of OLP was calculated as;

$\mathrm{Y}_{\mathrm{OLP}}=\frac{\mathrm{m}_{\mathrm{OLP}}}{\mathrm{m}_{\mathrm{i}}} \times 100 \%$

where YoLP is the OLP yield ( $\% \mathrm{w} / \mathrm{w})$, moLP is the OLP mass $(\mathrm{g})$, and $\mathrm{m}_{\mathrm{i}}$ is the mass of the raw material (g). 


\subsection{Experimental design}

The operating variables selected were temperature $\left(\mathrm{X}_{\mathrm{T}}\right)$, catalyst loading $\left(\mathrm{X}_{\mathrm{C}}\right)$, and ratio of catalyst mixture between ZSM- 5 and Y-Re- 16 ( $\mathrm{X}_{\mathrm{M}}$ ). In this study, the catalysts loaded consists of two types (ZSM- 5 and Y-Re-16). The catalyst loading is defined as the ratio between the total mass of catalyst and the mass of UCO. The ratio of catalyst mixture is defined as the ratio between mass of ZSM-5 and the total mass of catalyst. They are shown as Eqs.(2), and (3). The RSM combined with CCD was used for design experimental of the variables as shown in Table .2 There were discussed at 5 levels, code $-\alpha,-1,0,+1$, and $+\alpha$ ( $\alpha$ is equal to 2). The total number of experiment was 20 , shown in Table 3. The organic liquid yield was used to indicate the best condition. Minitab was used to analyze the result of organic liquid yield for finding a regression second-order polynomial model, main effects, interaction effects and the highest organic liquid yield. The relationship of four variables was presented by regression second- order polynomial model as shown in Eq. (4).

$$
\begin{aligned}
& \mathrm{X}_{\mathrm{C}}=\frac{\mathrm{mc}}{\mathrm{mUCO}} \\
& \begin{aligned}
\mathrm{X}_{\mathrm{M}} & =\frac{\mathrm{mZSM}-5}{\mathrm{mc}} \\
\mathrm{Y} & =\mathrm{k}_{0}+\mathrm{k}_{\mathrm{T}} \mathrm{X}_{\mathrm{T}}+\mathrm{k}_{\mathrm{C}} \mathrm{X}_{\mathrm{C}}+\mathrm{k}_{\mathrm{M}} \mathrm{X}_{\mathrm{M}}+\mathrm{k}_{\mathrm{TC}} \mathrm{X}_{\mathrm{T}} \mathrm{X}_{\mathrm{C}}+\mathrm{k}_{\mathrm{TM}} \mathrm{X}_{\mathrm{T}} \mathrm{X}_{\mathrm{M}} \\
& +\mathrm{kCMX}_{\mathrm{CM}}+\mathrm{kTT}_{\mathrm{TT}} \mathrm{X}_{\mathrm{TT}}+\mathrm{k}_{\mathrm{CC}} \mathrm{X}_{\mathrm{CC}}+\mathrm{kMM}_{\mathrm{MM}}
\end{aligned}
\end{aligned}
$$

where $\mathrm{m}_{\mathrm{c}}$, muco, and $\mathrm{m}_{\mathrm{ZSM}-5}$ are the catalyst, used cooking oil, and ZSM-5 catalyst mass (g). Y is the predicted yield of the OLP, $\mathrm{k}_{0}$ is model constant; $\mathrm{X}_{\mathrm{T}}, \mathrm{X}_{\mathrm{C}}$, and $\mathrm{X}_{\mathrm{M}}$ correspond to temperature, catalyst loading, and ratio of catalyst mixture; $\mathrm{kT}_{\mathrm{T}}, \mathrm{k}_{\mathrm{c}}$, kM are linear coefficients; $\mathrm{k}_{\mathrm{TT}}$, $\mathrm{kCC}_{\mathrm{C}}$, and $\mathrm{kMM}_{\mathrm{MM}}$ are the quadratic coefficients; and $\mathrm{k}_{\mathrm{TC}}, \mathrm{k}_{\mathrm{CM}}$, and $\mathrm{k}_{\mathrm{TM}}$ are the cross product coefficients, respectively.

\subsection{Analysis of optimized OLP}

The OLPs obtained at the optimum condition were analyzed using gas chromatography and mass spectrometry (GC-MS) at Science and Technology Service Center, Faculty of Science, Chiang Mai University. The main components of the OLP were classified into three main groups; gasoline $\left(\mathrm{C}_{7}-\mathrm{C}_{11}\right)$, kerosene $\left(\mathrm{C}_{12}-\mathrm{C}_{15}\right)$, and diesel $\left(\mathrm{C}_{16}-\mathrm{C}_{21}\right)$ like hydrocarbons (Khammasan et al., 2018; Maher and Bressler, 2007). The selectivity was estimated as;

$\mathrm{S}=\frac{\text { mass of concerned product }}{\text { mass of total product }} \times 100 \%$

Physical properties of the OLP were analyzed using similar standard procedures used for bio-oil (heating value and viscosity). The heating value of the OLP was determined by ASTM D240 and the viscosity was measured based on ASTM D445.

\section{Results and Discussion}

In this study, the products from the catalytic cracking of UCO were liquid, solid residue, and gas. The liquid product was focused and it was analyzed; viscosity, higher heating value, and the chemical composition

\subsection{Effect of ZSM-5 and Y-Re-16 catalysts}

Fig. 2 shows the OLPs produced from thermal and catalytic cracking of UCO. Three main components based on their carbon number including gasoline $\left(\mathrm{C}_{7}-\mathrm{C}_{11}\right)$, kerosene $\left(\mathrm{C}_{12}-\mathrm{C}_{15}\right)$, and diesel $\left(\mathrm{C}_{16}-\mathrm{C}_{21}\right)$ were illustrated. The main composition from thermal cracking was $73.6 \%$ diesel, which was long-chain and high molecular weight hydrocarbons. The catalyst cracking with ZSM-5 and Y-Re16 shows good results. It can be observed that gasoline and kerosene increased more from catalytic cracking than thermal cracking. The ZSM-5 and Y-Re-16 catalysts showed both primary and secondary cracking. It was expected that the diesel corrected from primary cracking on carbonyl group of triglycerides, gasoline and kerosene may be received by the secondary cracking of the primary cracking product. It was shown that the ZSM-5 and Y-Re16 were significant in generating the light hydrocarbon fuels.

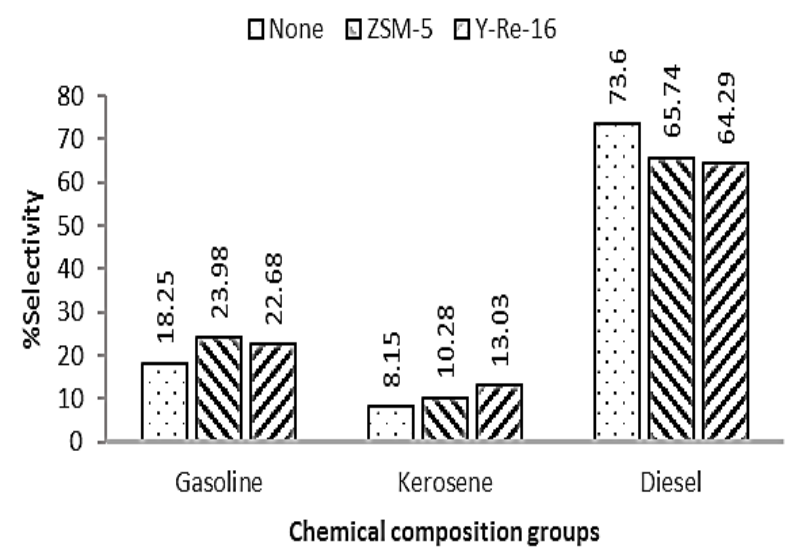

Fig. 2 Main composition of OLP from cracking with/without ZSM5 and Y-Re-16

\subsection{OLPs from catalytic cracking of UCO}

The results from catalytic cracking of UCO are shown in Table 3 against test conditions designated from the statistical design. The organic liquid yield obtained was between 70.4 to $83.9 \%$ w/w. Each catalyst can produce more light oils from cracking. When both were used in catalytic cracking, they can increase the yields of OLPs and short chain hydrocarbons. The significant parameters and model were analyzed statistically by ANOVA with 95 $\%$ confidence level. The $p$-value and f-value identify the influence level of each parameter (Yin et al., 2012). The significant parameters were present as smaller p-value and higher f-value (Istadi et al., 2006). At $95 \%$ confidence level, p-value under 0.05 and high f-value represent the large effect factors (Mazaheri et al., 2010). The result of ANOVA analysis is shown in Table 4. A good correlation between the experiment and the prediction was apparent with $\mathrm{R}^{2}=0.91$. It indicates that exceptional acceptance between experiment and predicted OLP yields. 
Citation: Onlamnao, K., Phromphithak, S., and Tippayawong, N. (2020) Generating organic liquid products from catalytic cracking of used cooking oils over mechanically mixed catalysts. Int. Journal of Renewable Energy Development, 9(2),157-166, doi: 10.14710/ijred.9.2.157-166

$\mathrm{P}$ a g e $\mid 162$

Table 2

Parameter and levels used of experimental design

\begin{tabular}{lccccc}
\hline Parameters & \multicolumn{4}{c}{ Level } \\
\cline { 2 - 6 } & $-\alpha$ & -1 & 0 & +1 \\
\hline Temperature, $\mathrm{X}_{\mathrm{T}}\left({ }^{\circ} \mathrm{C}\right)$ & 300 & 350 & 400 & 450 & 500 \\
Catalyst loading, $\mathrm{X}_{\mathrm{C}}(\% \mathrm{w} / \mathrm{w})$ & 5 & 8.75 & 12.5 & 16.25 & 20 \\
Ratio of catalyst mixture, $\mathrm{X}_{\mathrm{M}}\left(\% \mathrm{WzSM}-5_{\mathrm{y}} / \mathrm{W}_{\text {catalyst loading) }}\right.$ & 0 & 25 & 50 & 75 & 100 \\
\hline
\end{tabular}

Table 3

OLP yields as a function of temperature, catalyst loading and ratio of mixed catalyst.

\begin{tabular}{|c|c|c|c|c|c|c|c|c|}
\hline \multirow[t]{2}{*}{ Test } & \multicolumn{5}{|c|}{ Condition } & \multirow{2}{*}{$\begin{array}{l}\text { OLP yield } \\
(\% \mathrm{w} / \mathrm{w})\end{array}$} & \multirow{2}{*}{$\begin{array}{c}\text { Predicted } \\
\text { yield of OLP } \\
(\% \mathrm{w} / \mathrm{w})\end{array}$} & \multirow{2}{*}{$\begin{array}{c}\text { Difference } \\
(\%)\end{array}$} \\
\hline & $\mathrm{X}_{\mathrm{T}}\left({ }^{\circ} \mathrm{C}\right)$ & $\mathrm{X}_{\mathrm{C}}(\% \mathrm{w} / \mathrm{w})$ & $\mathrm{X}_{\mathrm{M}}(\% \mathrm{w} / \mathrm{w})$ & $\begin{array}{l}\text { ZSM-5 } \\
(\% \mathrm{w} / \mathrm{w})\end{array}$ & Y-Re-16 (\%w/w) & & & \\
\hline 1 & 350 & 8.75 & 25 & 2.1875 & 6.5625 & 82.92 & 83.36 & 0.53 \\
\hline 2 & 450 & 8.75 & 25 & 2.1875 & 6.5625 & 80.15 & 77.31 & -3.54 \\
\hline 3 & 350 & 16.25 & 25 & 4.0625 & 12.1875 & 79.98 & 79.21 & -0.96 \\
\hline 4 & 450 & 16.25 & 25 & 4.0625 & 12.1875 & 75.30 & 73.15 & -2.86 \\
\hline 5 & 350 & 8.75 & 75 & 6.5625 & 2.1875 & 83.99 & 83.36 & -0.75 \\
\hline 6 & 450 & 8.75 & 75 & 6.5625 & 2.1875 & 75.59 & 77.31 & 2.28 \\
\hline 7 & 350 & 16.25 & 75 & 12.1875 & 4.0625 & 81.09 & 79.21 & -2.32 \\
\hline 8 & 450 & 16.25 & 75 & 12.1875 & 4.0625 & 73.42 & 73.15 & -0.37 \\
\hline 9 & 400 & 12.5 & 50 & 6.25 & 6.25 & 78.55 & 78.26 & -0.37 \\
\hline 10 & 400 & 12.5 & 50 & 6.25 & 6.25 & 79.53 & 78.26 & -1.60 \\
\hline 11 & 400 & 12.5 & 50 & 6.25 & 6.25 & 80.59 & 78.26 & -2.89 \\
\hline 12 & 400 & 12.5 & 50 & 6.25 & 6.25 & 76.24 & 78.26 & 2.65 \\
\hline 13 & 300 & 12.5 & 50 & 6.25 & 6.25 & 82.81 & 84.31 & 1.81 \\
\hline 14 & 500 & 12.5 & 50 & 6.25 & 6.25 & 70.35 & 72.20 & 2.63 \\
\hline 15 & 400 & 5.0 & 50 & 2.5 & 2.5 & 83.15 & 82.41 & -0.89 \\
\hline 16 & 400 & 20 & 50 & 10 & 10 & 72.97 & 74.10 & 1.55 \\
\hline 17 & 400 & 12.5 & 0 & 0 & 12.5 & 75.70 & 78.26 & 3.38 \\
\hline 18 & 400 & 12.5 & 100 & 12.5 & 0 & 77.14 & 78.26 & 1.45 \\
\hline 19 & 400 & 12.5 & 50 & 6.25 & 6.25 & 78.74 & 78.26 & -0.61 \\
\hline 20 & 400 & 12.5 & 50 & 6.25 & 6.25 & 79.72 & 78.26 & -1.83 \\
\hline
\end{tabular}

Table 4.

ANOVA for OLP yield.

\begin{tabular}{|c|c|c|c|c|c|c|}
\hline Source & $\mathrm{DF}$ & Adj SS & Adj MS & F-Value & P-value & Comment \\
\hline Model & 10 & 240.818 & 24.082 & 9.110 & 0.001 & \\
\hline Blocks & 1 & 5.789 & 5.789 & 2.190 & 0.173 & \\
\hline $\mathrm{X}_{\mathrm{T}}$ & 1 & 146.660 & 146.660 & 55.500 & 0.000 & Significant \\
\hline $\mathrm{X}_{\mathrm{C}}$ & 1 & 68.963 & 68.963 & 26.100 & 0.001 & Significant \\
\hline $\mathrm{X}_{\mathrm{M}}$ & 1 & 0.117 & 0.117 & 0.040 & 0.838 & Insignificant \\
\hline $\mathrm{X}_{\mathrm{T}} * \mathrm{X}_{\mathrm{T}}$ & 1 & 2.632 & 2.632 & 1.000 & 0.344 & Insignificant \\
\hline $\mathrm{X}_{\mathrm{C}} * \mathrm{X}_{\mathrm{C}}$ & 1 & 0.037 & 0.037 & 0.010 & 0.908 & Insignificant \\
\hline $\mathrm{X}_{\mathrm{M}} * \mathrm{X}_{\mathrm{M}}$ & 1 & 3.319 & 3.319 & 1.260 & 0.291 & Insignificant \\
\hline $\mathrm{X}_{\mathrm{T}} * \mathrm{X}_{\mathrm{C}}$ & 1 & 0.173 & 0.173 & 0.070 & 0.804 & Insignificant \\
\hline $\mathrm{X}_{\mathrm{T}} * \mathrm{X}_{\mathrm{M}}$ & 1 & 9.299 & 9.299 & 3.520 & 0.093 & Insignificant \\
\hline $\mathrm{X}_{\mathrm{C}} * \mathrm{X}_{\mathrm{M}}$ & 1 & 0.924 & 0.924 & 0.350 & 0.569 & Insignificant \\
\hline Error & 9 & 23.782 & 2.642 & & & \\
\hline Lack-of-Fit & 5 & 12.947 & 2.589 & 0.960 & 0.532 & \\
\hline Pure Error & 4 & 10.835 & 2.709 & & & \\
\hline Total & 19 & 264.601 & & & & \\
\hline
\end{tabular}


To improve the model, insignificance terms were eliminated. The ANOVA result showed two linear significant terms; temperature $\left(\mathrm{X}_{\mathrm{T}}\right)$ and catalyst loading $\left(\mathrm{X}_{\mathrm{C}}\right)$, while the square and interaction terms were insignificance. The model was re- analyzed to create a revised model. The new predicted equation model of the OLPs yield is shown in Eq. (5),

$\mathrm{Y}=109.40-0.06055 \mathrm{X}_{\mathrm{T}}-0.554 \mathrm{X}_{\mathrm{C}}$

where $\mathrm{Y}=$ OLPs yield $(\% \mathrm{w} / \mathrm{w}) ; \mathrm{X}_{\mathrm{T}}=$ temperature $\left({ }^{\circ} \mathrm{C}\right) ; \mathrm{X}_{\mathrm{C}}=$ catalyst loading $(\% \mathrm{w} / \mathrm{w})$; and $\mathrm{X}_{\mathrm{M}}=$ ratio of catalyst mixture $(\% \mathrm{w} / \mathrm{w})$. The predicted equation was determined by backward elimination and multi-regression from the data of experiments. The polynomial model for the organic liquid yield was regressed by considering only the significant term. The optimum condition of the experiment was solved using Minitab software. At the predicted optimum condition $\left(300{ }^{\circ} \mathrm{C}\right.$, and $5 \% \mathrm{w} / \mathrm{w}$ catalyst loading), the highest OLP yields were 88.6 and $84.8 \%$ for predicted and average experimental values, respectively.

Also shown in Table 3, predicted OLP yields were within $3.5 \%$ of the experimental values for all cases. The predicted and experimental values were comparable with marginal difference. The surface plot used to present the relation between OLP yield with temperature and catalyst is shown in Fig. 3. The significant terms are temperature and catalyst. They are in linear relationships to the OLP yields where maximum occurs at low temperature and catalyst loading.

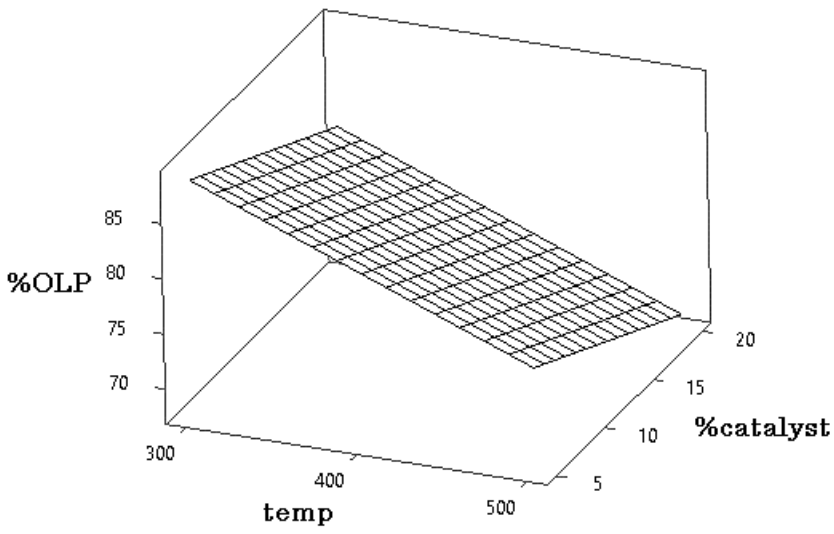

Fig. 3 Surface plot of the reduced model

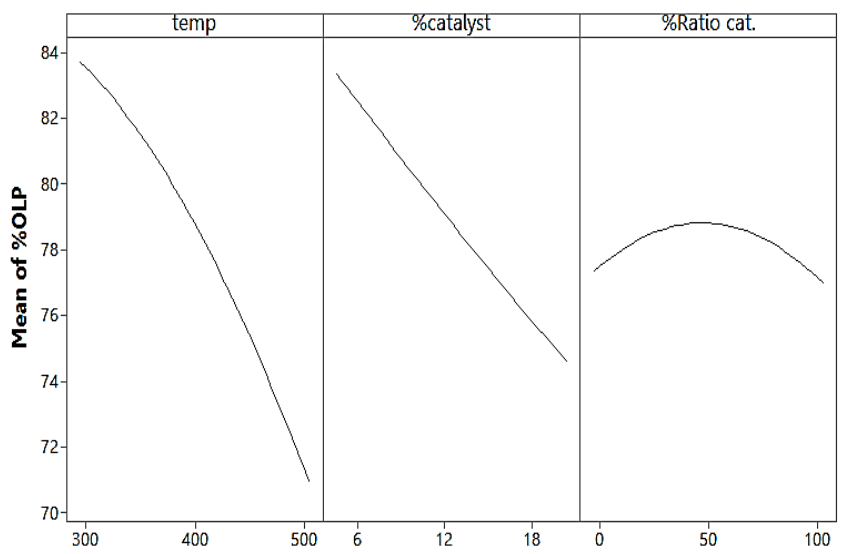

Fig. 4 Main effects on the OLP yields
The main effect is shown in Fig. 4 Temperature and catalyst loading were observed to be significant. From, Fig 4(a), high temperature had a negative effect on the OLP yield because increasing temperature led to higher light oil vapor. Some light oil was unable to condense into OLPs (Rofiqulislam et al., 2008). Effect of catalyst loading is presented in Fig. 4(b). Increasing catalyst loading was found to decrease the OLP yield possibly from coke formation. The coke formation affected surface area on the catalyst (Kim et al., 2020). The ratio of mixed catalyst did not show strong effect within the range of condition studied as shown in Fig 4(c). Both ZSM-5 and Y-Re-16 catalysts can produce light oil from cracking of long-chain hydrocarbons to short chain hydrocarbons. The OLP yield was found to increase at $50 \%$ mixed catalyst. It seemed that different structures of catalysts can improve cracking reaction, however, it had relatively lower effect than other parameters.

Although the interaction effects are statistically insignificant, Fig. 5 implied the interaction of three operating parameters on the OLP yield. The effect of temperature with the catalyst loading on the OLP yield is shown in Fig. 5 (a). It was found that these parameters did not affect the OLP yield much within the range of condition studied. Similarly, the effects of the mixed catalyst with the temperature on the OLP yield and the catalyst loading are shown in Fig. 5(b) and Fig. 5(c), respectively. Both of them displayed the result in similar fashion.

\subsection{Analysis of the OLP}

The OLP obtained at the optimum condition was analyzed for chemical composition, viscosity, and higher heating value via GC- MS, ASTM- 445D, and ASTM- 240D, respectively. The result of physical analysis is shown in Table. 5. The result of chemical analysis is shown in terms of the number of carbon atom in Fig. 6. The main components in the UCO were triglycerides consisting of the glycerol and the fatty acids. The fatty acid part shows $\mathrm{C}_{12}-\mathrm{C}_{24}$ detected, in which $\mathrm{C}_{16}$ and $\mathrm{C}_{18}$ were the major components. Meanwhile, the OLP contained lighter molecular weight and short- chain hydrocarbons, consisting of $\mathrm{C}_{9}-\mathrm{C}_{18}$. It was indicated that thermal cracking reaction began at the optimized condition with relatively low temperature $\left(300{ }^{\circ} \mathrm{C}\right.$ ) using only small amount of catalysts $(5 \% \mathrm{w} / \mathrm{w})$, leading to decomposition of triglycerides to light fatty acids (Mancio et al., 2016). The catalyst mixture ratio of $97 \% \mathrm{w} / \mathrm{w}$ at the optimum condition implied that Y-zeolite did not significantly affect the OLP yield. This was because its large pore size may have affected coke and non-condensable gases in the UCO (Mante et al., 2014). The ZSM- 5 was more effective in generating light liquid products.

The chemical components in the OLP may be classified into five groups, including alicyclic hydrocarbon, paraffins, olefins, ketones, and carboxylic acids. Fig. 7 shows the percentage of the component groups in the OLP consisting of carboxylic acids $(\sim 76 \%)$, olefins $(\sim 9 \%)$, alicyclic hydrocarbons $(\sim 7 \%)$, paraffins $(\sim 6 \%)$, and ketones $(\sim 1 \%)$. The major component in the OLP was carboxylic acid, which was expected from the primary cracking. There were a small amount of secondary cracking organic liquids that were hydrocarbons including olefins, paraffins, and 
alicyclics. Only ketones were dehydrogenated from carboxylic acids. . It can be seen that the catalysts were selective to the primary cracking. The catalysts can improve its performance for the secondary cracking via increasing porousity (Ibarra et al., 2019), nano particles (Ahmad et al., 2016), and metal doping such as Ni, Cu, and Zn ( Li et al., 2018; Cheng et al., 2019). These light hydrocarbons can be divided into three groups of fuels by the carbon atom number, namely gasoline $12.11 \%$, kerosene $8.95 \%$, and diesel $71.43 \%$. According to the physical properties, the energy content of the OLP and UCO were slightly different, 36.4 and $39 \mathrm{MJ} / \mathrm{kg}$, while the viscosity of the OLP $(7.93 \mathrm{cSt})$ was smaller than that of the $\mathrm{UCO}$, and in the range of commercial diesels in Thailand.

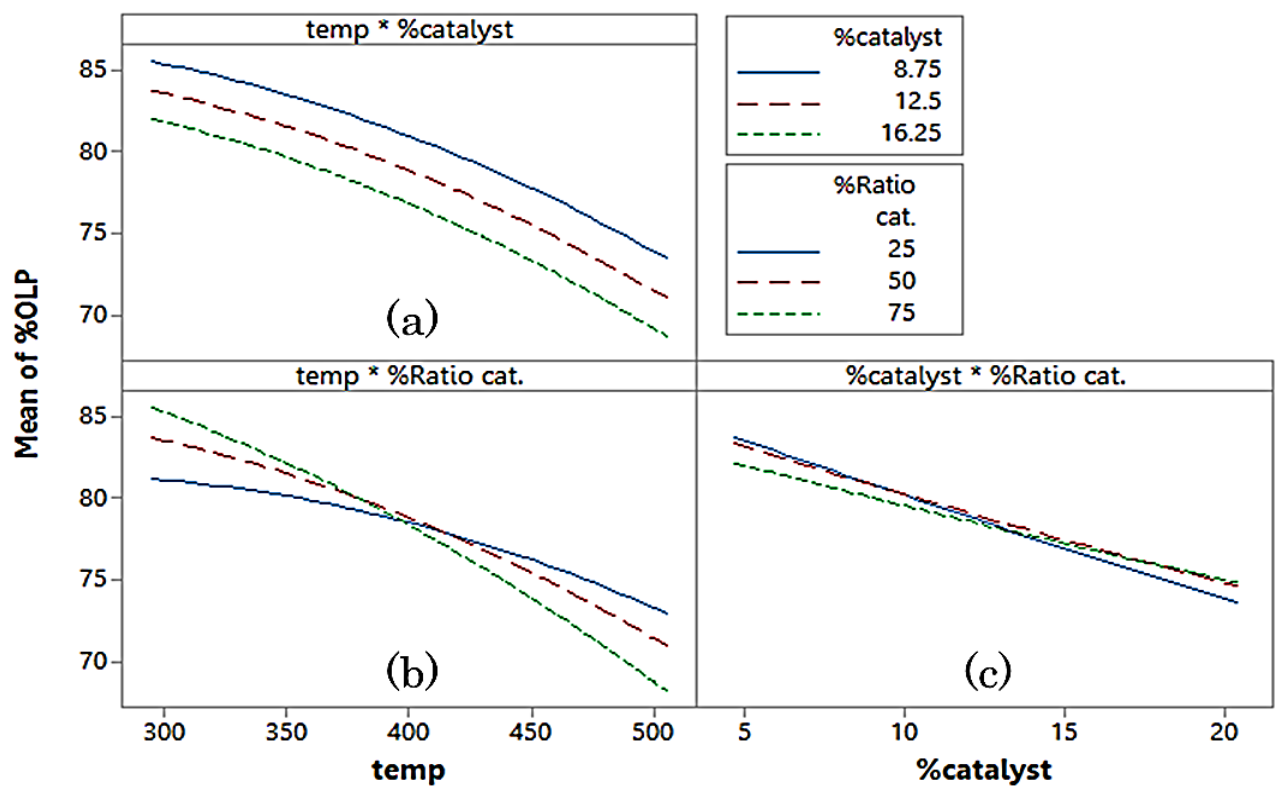

Fig. 5 Interaction effect on OLP

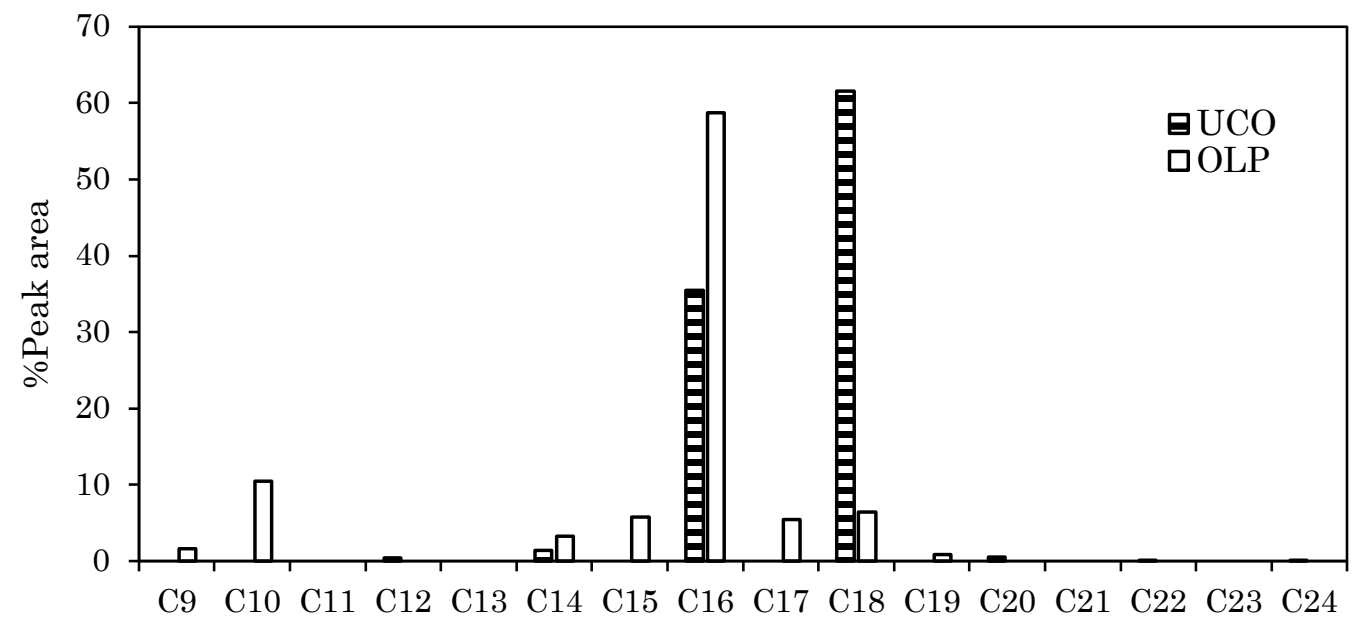

Fig. 6 The component of the UCO and OLP in terms of carbon number.

Table 5

Physical properties of the OLP and UCO.

\begin{tabular}{lllll}
\hline Fuel oil & Parameter & Unit & Standard & value \\
\hline Optimum OLP & Viscosity & cSt & ASTM D445 & $7.933 \pm 0.001$ \\
& HHV & MJ/kg & ASTM D240 & $8693 \pm 28$ \\
UCO & Viscosity & $\mathrm{cSt}$ & ASTM D445 & $41.050 \pm 0.014$ \\
& HHV & MJ/kg & ASTM D240 & $9318 \pm 44$ \\
Diesel (Thai community standard) & Viscosity & $\mathrm{cSt}$ & ASTM D445 & $1.9-8.0$ \\
& HHV & n/a & n/a & n/a \\
\hline
\end{tabular}




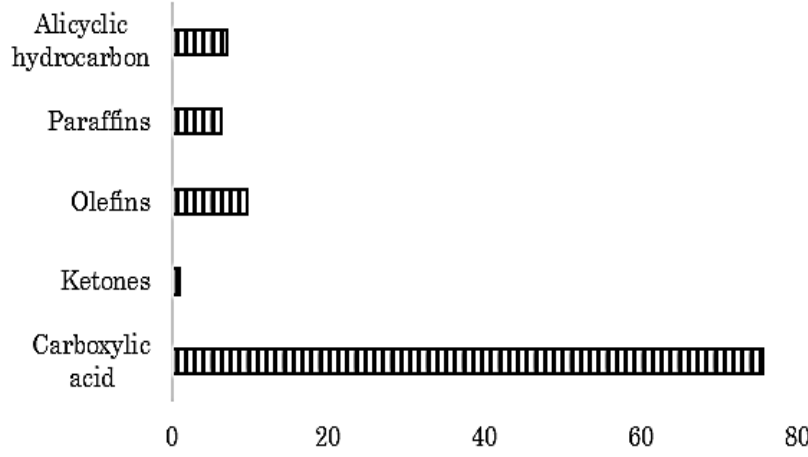

Fig. 7 Main groups of components in the OLP

\section{Conclusion}

Liquid bio-fuel may be generated from catalytic cracking of waste cooking oil. In this work, catalytic cracking of UCO with mixed catalysts between ZSM- 5 and Y-Re- 16 were studied. The highest OLP yield was obtained at low temperature and catalyst loading with ZSM- $5\left(300^{\circ} \mathrm{C}, 5 \%\right.$ catalyst loading, 97\% ZSM-5). High temperature and high catalyst loading were found to promote lighter hydrocarbons which were in the group of gasoline and kerosene.ZSM-5 and Y-Re-16 appeared to generate similar OLP composition in catalytic cracking of the UCO. The selectivity of gasoline, kerosene, and diesel were 12.11 , 8.95, and $71.43 \%$, respectively. The viscosity and HHV of the OLP were within the Thailand community diesel standard. It was shown that the catalytic cracking of UCO offers alternative route to generate biofuels, but the costeffectiveness should be further addressed.

\section{Acknowledgments}

This research was partially supported by Chiang Mai University and the Research Assistantship program from the CMU Graduate School and Faculty of Engineering.

\section{References}

Ahmad, M., Farhana, R., Raman, A.A.A., Bhargava, S.K., 2016. Synthesis and activity evaluation of heterometallic nano oxides integrated ZSM-5 catalysts for palm oil cracking to produce biogasoline. Energy Conversion and Management 119 , $352-360$. https://doi.org/10.1016/j.enconman.2016.04.069

Al Sharifi, M., Znad, H., 2019. Transesterification of waste canola oil by lithium/zinc composite supported on waste chicken bone as an effective catalyst. Renewable Energy, https://doi.org/10.1016/j.renene.2019.11.071

Anderson, M., Whitcomb, P., 2001. Design of Experiments: Statistical Principles of Research Design and Analysis. Technometrics 43 , 236-237. https://doi.org/10.1198/tech.2001.s589

Benavides, P.T., Cronauer, D.C., Adom, F., Wang, Z., Dunn, J.B., 2017. The influence of catalysts on biofuel life cycle analysis (LCA). Sustainable Materials and Technologies 11, 53-59. https://doi.org/10.1016/j.susmat.2017.01.002

Cheng, J., Zhang, Z., Zhang, X., Liu, J., Zhou, J., Cen, K., 2019. Sulfonated mesoporous $\mathrm{Y}$ zeolite with nickel to catalyze hydrocracking of microalgae biodiesel into jet fuel range hydrocarbons. International Journal of Hydrogen Energy 44, 1650-1658. https://doi.org/10.1016/j.ijhydene.2018.11.110

Corma, A., Huber, G., Sauvanaud, L., Oconnor, P., 2007. Processing biomass-derived oxygenates in the oil refinery: Catalytic cracking (FCC) reaction pathways and role of catalyst. Journal of Catalysis 247, 307-327. https://doi.org/10.1016/j.jcat.2007.01.023

Crabbe, E., Nolasco-Hipolito, C., Kobayashi, G., Sonomoto, K., Ishizaki, A., 2001. Biodiesel production from crude palm oil and evaluation of butanol extraction and fuel properties. Process Biochemistry 37, 65-71. https://doi.org/10.1016/S0032-9592(01)00178-9

Emori, E.Y., Hirashima, F.H., Zandonai, C.H., Ortiz-Bravo, C.A., Fernandes-Machado, N.R.C., Olsen-Scaliante, M.H.N., 2017. Catalytic cracking of soybean oil using ZSM5 zeolite. Catalysis Today 279, 168-176. https://doi.org/10.1016/j.cattod.2016.05.052

Hosseinpour, N., Mortazavi, Y., Bazyari, A., Khodadadi, A.A., 2009. Synergetic effects of Y-zeolite and amorphous silicaalumina as main FCC catalyst components on triisopropylbenzene cracking and coke formation. Fuel Processing Technology 90, 171-179. https://doi.org/10.1016/j.fuproc.2008.08.013

Ibrahim, S.H., Hamza, E., 2017. Optimization of lipid extraction from municipal scum sludge for biodiesel production using statistical approach. International Journal of Renewable $\begin{array}{llll}\text { Energy Development } & 6,\end{array}$ https://doi.org/10.14710/ijred.6.2.171-179

Ibarra, Á., Hita, I., Azkoiti, M.J., Arandes, J.M., Bilbao, J., 2019. Catalytic cracking of raw bio-oil under FCC unit conditions over different zeolite-based catalysts. Journal of Industrial and Engineering Chemistry 78, 372-382. https://doi.org/10.1016/j.jiec.2019.05.032

Istadi, Amin N.A.S., 2006, Optimization of process parameters and catalyst composition in carbon dioxide oxidative coupling of methane over $\mathrm{CaO}-\mathrm{MnO} / \mathrm{CeO} 2$ catalyst using response surface methodology, Fuel Processing Technology, 87(5), 44959.

Jaroenkhasemmeesuk, C., Diego, M.E., Tippayawong, N., Ingham, D.B., Pourkashanian, M., 2018. Simulation analysis of the catalytic cracking process of biomass pyrolysis oil with mixed catalysts: Optimization using the simplex lattice design. International Journal of Energy Research, 42, 29832996. https://doi.org/10.1002/er.4023

Kadarwati, S., 2015. Polymerisation and coke formation during mild hydrotreatment of bio-oil over pre-sulphided co-Mo/Y$\mathrm{Al} 2 \mathrm{O} 3$ catalyst. International Journal of Renewable Energy Development 4, 32-38. https://doi.org/10.14710/ijred.4.1.3238

Karmaker, A.K., Rahman, Md.M., Hossain, Md.A., Ahmed, Md.R., 2020. Exploration and corrective measures of greenhouse gas emission from fossil fuel power stations for Bangladesh. Journal of Cleaner Production 244, 118645. https://doi.org/10.1016/j.jclepro.2019.118645

Khammasan T., Tippayawong N., 2018, Light liquid fuel from catalytic cracking of beef tallow with ZSM-5, International Journal of Renewable Energy Research, 8, 407-413.

Khuenkaeo, N., Tippayawong, N., 2018. Bio-oil production from ablative pyrolysis of corncob pellets in a rotating blade Reactor. IOP Conf. Ser.: Earth Environ. Sci. 159, 012037. https://doi.org/10.1088/1755-1315/159/1/012037

Khuenkaeo, N., Tippayawong, N., 2020. Production and characterization of bio-oil and bio-char from ablative pyrolysis of lignocellulosic biomass residues. Chemical Engineering Communications, 207(2), 153-160. 
Kim, S., Sasmaz, E., Pogaku, R., Lauterbach, J., 2020. Effects of reaction conditions and organic sulfur compounds on coke formation and HZSM-5 catalyst performance during jet propellant fuel (JP-8) cracking. Fuel 259, 116240. https://doi.org/10.1016/j.fuel.2019.116240

Li, C., Ma, J., Xiao, Z., Hector, S.B., Liu, R., Zuo, S., Xie, X., Zhang, A., Wu, H., Liu, Q., 2018. Catalytic cracking of Swida wilsoniana oil for hydrocarbon biofuel over Cu-modified ZSM5 zeolite. Fuel 218, 59-66. https://doi.org/10.1016/j.fuel.2018.01.026

Li, L., Yuan, X., Wang, Y., Sun, B., Wu, D., 2019. A two-layer fuzzy synthetic strategy for operational performance assessment of an industrial hydrocracking process. Control Engineering Practice 93, 104187.

Maher, K.D., Bressler, D.C., 2007. Pyrolysis of triglyceride materials for the production of renewable fuels and chemicals. Bioresource Technology 98, 2351-2368. https://doi.org/10.1016/j.biortech.2006.10.025

Mancio, A.A., da Costa, K.M.B., Ferreira, C.C., Santos, M.C., Lhamas, D.E.L., da Mota, S.A.P., Leão, R.A.C., de Souza, R.O.M.A., Araújo, M.E., Borges, L.E.P., Machado, N.T., 2016. Thermal catalytic cracking of crude palm oil at pilot scale: Effect of the percentage of $\mathrm{Na} 2 \mathrm{CO} 3$ on the quality of biofuels. Industrial Crops and Products 91, 32-43.

Mante O.D., Agblevor F.A., Oyama S.T., McClung R., 2014, Catalytic pyrolysis with ZSM-5 based additive as co-catalyst to Y-zeolite in two reactor configurations, Fuel, 117, 649-659.

Mazaheri H., Lee K.T., Bhatia S., Mohamed A.R., 2010, Subcritical water liquefaction of oil palm fruit press fiber in the presence of sodium hydroxide: an optimization study using response surface methodology, Bioresource Technology, 101(23), 9335-9341.

Nguyen, H.C., Nguyen, M.L., Wang, F.-M., Liang, S.-H., Bui, T.L., Ha, H.H., Su, C.-H., 2019. Using switchable solvent as a solvent and catalyst for in situ transesterification of spent coffee grounds for biodiesel synthesis. Bioresource Technology 289, 121770. https://doi.org/10.1016/j.biortech.2019.121770

Pascoal, C.V.P., Oliveira, A.L.L., Figueiredo, D.D., Assunção, J.C.C., 2020. Optimization and kinetic study of ultrasonicmediated in situ transesterification for biodiesel production from the almonds of Syagrus cearensis. Renewable Energy 147, 1815-1824. https://doi.org/10.1016/j.renene.2019.09.122

Prasertpong, P., Tippayawong, N., 2019. Upgrading of biomass pyrolysis oil model compound via esterification: Kinetic study using heteropoly acid. Energy Procedia 160, 253-259. https://doi.org/10.1016/j.egypro.2019.02.144

Prasertpong, P., Jaroenkhasemmeesuk, C., Regalbuto, J.R., Lipp, J., Tippayawong, N., 2020. Optimization of process variables for esterification of bio-oil model compounds by a heteropolyacid catalyst. Energy Reports 6, 1-9. https://doi.org/10.1016/j.egyr.2019.11.026

Rathore, V., Newalkar, B.L., Badoni, R.P., 2016. Processing of vegetable oil for biofuel production through conventional and non-conventional routes. Energy for Sustainable Development $31, \quad 24-49$. https://doi.org/10.1016/j.esd.2015.11.003

Rofiqulislam, M., Haniu, H., Rafiqulalambeg, M., 2008. Liquid fuels and chemicals from pyrolysis of motorcycle tire waste: Product yields, compositions and related properties. Fuel 87, 3112-3122. https://doi.org/10.1016/j.fuel.2008.04.036

Schipper, P.H., Dwyer, F.G., Sparrell, P.T., Mizrahi, S., Herbst, J.A., 1988. Zeolite ZSM-5 in Fluid Catalytic Cracking: Performance, Benefits, and Applications, in: Occelli, M.L. (Ed.), Fluid Catalytic Cracking. American Chemical Society, Washington, DC, pp. 64-86. https://doi.org/10.1021/bk-19880375.ch005

Suwannapa, P., Tippayawong, N., 2017. Optimization of two-step biodiesel production from beef tallow with microwave heating. Chemical Engineering Communications 204(5), 618-624.

Syah Putra, R., Shabur Juliantoa, T., Hartono, P., Dyah Puspitasaria, R., Kurniawan, A., 2014. Pre-treatment of usedcooking oil as feed stocks of biodiesel production by using activated carbon and clay minerals. International Journal of Renewable Energy Development 3, 33-35. https://doi.org/10.14710/ijred.3.1.33-35

US EIA, 1997. Petroleum product supplied (consumption). Retrieved on November 11, 2019, from: https://www.eia.gov/dnav/pet/pet_cons_psup_dc_nus_mbblpd _a.htm

Wu, Y., Wang, X., Song, Q., Zhao, L., Su, H., Li, H., Zeng, X., Zhao, D., Xu, J., 2018. The effect of temperature and pressure on nheptane thermal cracking in regenerative cooling channel. Combustion and Flame 194, 233-244. https://doi.org/10.1016/j.combustflame.2018.04.036

Yin p., Chen L., Wang Z., Qu R., Liu X., Ren S., 2012, Production of biodiesel by esterification of oleic acid with ethanol over organophosphonic acid-functionalized silica, Bioresource Technology, 110, 258-263.

Zhao, X., Wei, L., Julson, J., Qiao, Q., Dubey, A., Anderson, G., 2015. Catalytic cracking of non-edible sunflower oil over ZSM5 for hydrocarbon bio-jet fuel. New Biotechnology 32, 300-312. https://doi.org/10.1016/j.nbt.2015.01.004

Zheng, Q., Huo, L., Li, H., Mi, S., Li, X., Zhu, X., Deng, X., Shen, B., 2017. Exploring structural features of USY zeolite in the catalytic cracking of Jatropha Curcas L. seed oil towards higher gasoline/diesel yield and lower $\mathrm{CO}_{2}$ emission. Fuel 202, 563-571. https://doi.org/10.1016/j.fuel.2017.04.073 